\title{
English Dominance and Its Influence on International Communication
}

\author{
Jiao Xue \\ English Department, Zhenjiang Watercraft College, Zhenjiang, China \\ Wenjing Zuo \\ English Department, Zhenjiang Watercraft College, Zhenjiang, China
}

\begin{abstract}
With the development of globalization and informatization, there is an undenied fact that more and more people from different countries are communicating and exchanging ideas with each other by one language, that is English. Whether you like English or not, if you want to enter into the wave of globalization and informatization, and conduct effective international communications, or you want to become an influential politician merchant and scientist, you must be able to use English to communicate. The dominance of English is like a snowball, too big to prevent. This thesis discusses the manifestation of English dominance and the necessity of analyzing English dominance. It analyses the reasons of formation of English dominance in international communication from the history of English language development, macro level, technical factors and other comprehensive aspects. Finally, the author analyses the influence English dominance brought to China.
\end{abstract}

Index Terms - international communication, English dominance, influence

Cultural hegemony taking place of colonialism is causing widespread concern. However, most studies on cultural hegemony focus on politics, philosophy and other fields. The author thinks that the spread and expansion of English makes English dominance more and more obvious in international communication.

\section{Language, Culture And Hegemony}

Language is the carrier of culture, and every language is the crystallization of each culture. It is the process of cultural exchange and cultural diffusion for people to use language to communicate with each other. Language users can gain a sense of cultural identity and social belongings through language. In general, the language of a nation is deeply rooted in national culture, and accompanied by national traditions. Language can not survive, develop and improve without culture. Language is the core of culture. There is no basis for the existence and continuation of culture without language. As a result, the national language has a vital role in maintaining ethic nationality. Language carries culture, but has inextricably association with politics and economy. Language has always been an effective tool for political and cultural struggle, an important means of maintaining and developing countries, and a significant part of national common culture. Culture is the reflection of politics and economy on ideology. Western powerful economic and political strength is bound to create and consolidate a strong position in their culture, thus showing an asymmetry tilt feature of global culture exchange, that is strong culture flow unidirectionally to vulnerable culture. As a result, weak culture is passive, and forced to absorb a large number of strong culture. Conversely, the strong culture is always in a dominant position, and it can select and deploy other culture according to its own needs to strengthen itself. As English is spread and used worldwide, it inevitably becomes an important tool for the output of Western culture, and even a means of Western countries to seek cultural hegemony.

E.Said points out in English dominance that in our modern era, most of the direct colonialism has been terminated, while dominance is still remaining in its place just as we see. It exists as a specific political, ideological, economic and social practices. Cultural dominance is the continuation of modern colonialism in cultural field. Its purpose is not to conquer territory, nor is to control the economic field, it is to control people's mind, which is a means to change power relations between two countries. In the background of economic globalization, with the deepening of cultural exchanges between countries, the emergence of cultural globalization is a trend. But it is not real equal exchange among countries around the world. It is cultural hegemony swayed by cultural dominance, which shows the dominance of strong culture over weak culture. Language advantages can be used to spread values, pursue national interests. America, Britain, and other English-speaking countries vigorously promote the expansion of English, making it become a global language. In a sense, it is culture wars at the level of language, and language is used as a weapon to violate other countries.

Cultural hegemony no longer solely refers to a non-violent culture domination form which a country's ruling class rules over ruled class. It includes non-violent ideological hegemony among countries, especially among western developed countries and Third world countries. As a colonist policy which Western countries conduct over Eastern countries, as a deep rooted thinking mode and power discourse, it does not exit the stage of history with the development of times. 


\section{Manifestation Mode of English Dominance in Media}

Firstly, the performance of English dominance in international communication is the number of people using English. Currently, there are 380 million people around the world using English as a native language and 250 million people using English as a second language. While, the number of people who are learning English is an even bigger figure. According to the estimation of English cultural council, the number of people around the world who are learning English reaches 1 billion and about 1.5 to 2 billion people are in contact with English. By 2050, half of the world's population will be proficient in using English.

Linguists divide the people using English that are mentioned above into three categories: the first category refers to the people, who are using English as their native language, and usually it is their only language. These people mainly live in the United States, Canada, Australia, New Zealand, Iceland, and South Africa. The second category refers to the people, who are using English as their second language. These people generally live in former British colonies and areas and regions which are greatly influenced by the United States, such as India, Nicaragua, Singapore, Philippines and Hong Kong of China. The third category refers to the people who are using English as a foreign language. Generally, these areas and regions do not have a close relationship with the United States.

Although the number of people who are speaking Chinese as their mother tongue is above 1.3 billion (including overseas Chinese), Chinese speaking population is limited to Chinese and foreign-country-born Chinese. After all, the foreign population using Chinese as their native language or their second language is much less. In these years, with the development of China's economy, there has been a increasing enthusiasm for learning Chinese, but it still can not be compared with the English boom.

In fact, English dominance in international communication is not only reflected in the population using English, but more reflected in the application range of English. After cold war, with the advent of globalization and information technology, English is widely used in various fields around the world, including politics, economy, trade, culture, diplomacy, tourism, communication, natural science and academic research of humanities, etc. According to the statistics, currently around the world, there are more than 60 countries using English as their official language, $85 \%$ of international organizations using English as their common language, and 75\% of the world's mail are written in English, $80 \%$ of publications and internet information is published in English.

English dominance in international communication is particularly evident in the field of scientific research. After World War I, instead of English, German became the main language of scientific research. But after World War II (especially 20 years after Cold War), America established the status of supremacy, English dominance became overwhelming. According to the investigation of thousands of copies of scientific journal in 1997 which is proposed by Professor Eugene Garfield, founder of SCI (Scientific Citation Index), 95\% of 925,000 scientific papers are written in English, half of which is written by authors from English speaking countries, and thus half of which is written by authors from non-English speaking countries. English dominance is evident.

English dominance in international communication is also very evident in our country, particularly in the last 20 years. The emergence of a large number of English language media is one example. So far, the English media which is based on news spreading includes an English TV channel, a foreign language radio station, 9 English daily and weekly newspapers, 10 magazines and 9 English websites. As a country with a non-English official language, it is a great achievement. But it also shows the importance of English language. These above statistics has not included the English newspapers which are based on English learning.

In addition to the English media, the vast number of people learning English is evident enough to explain the influence of English dominance. According to the statistics, there are about 30 million people in our country learning English and the number is still growing.

The emergence of English hot and our country's opening policy are closely related, and this is especially true after our country's entry into WTO. Now, English is not only compulsory for high and senior school students, but also compulsory for primary school students from third grade in the cities. English is also the compulsory subject for college and graduate entrance examination, and it is the necessary condition for the promotion of technical titles. In big cities like Shanghai, a person's English proficiency can also decide whether he can be international talents.

\section{The REASONS OF The Formation OF ENGLish DOMINANCE}

The formation of English dominance has gone through a long time. Just as Robert of Gloucester said before, English is a language that humble people spoke 1300 years ago. In the following 200 years, the development of English has undergone the period of old English, the period of French-influencing and the period of medi-evil English.1500 years later, modern English was taking shape, which mainly refers to the stable spelling pronunciation and meaning. However, English emerged as the international language after 19tth century. The main reasons are as follows:

Firstly, from the macroscopic view, the dominance of English is not precipitated by the language itself, so the arising of English dominance in international communication is not solely the dominance of language itself. Just as the professor Jean Aitchison in Oxford pointed out, the success of a language has much to do with the power of the people who use it but has little to do with internal features of the language.

It is very obvious in consideration to English. During the 18th century and 19th century, the influence of the British 
Empire began to spread around the world for the sake of industrial revolution, so English began to become popular. English was used not only in the British colonies but also in the diplomatic negotiations of non-English-speaking countries.

However, no matter how powerful the adaptively is and how large the area that the power of English covers, currently, the international status of English mainly springs from the status of America as a superpower after World War 2.

Besides, with the development of the economic globalization and new political structure, there is a great need of an international language. As result, English became the first choice.

Secondly, from the view of language, the dominance of English in international communication has a close relationship with the vitality of the language itself. On the one hand,English has a connection with all the Indo-European languages .Maybe it appears to be difficult to oriental people, but it is an easy job to western European and Russian people because the grammar and are similar to their mother language.

Compared with Indo-European languages, English also bears the unique characteristics of the "universal language", that is diversity, flexibility and adaptivity. Although the dominance of English originated from Britain and America, it is regarded as the official language bit is regarded as the official language by many countries in 5 continents. Meanwhile, the vocabulary of English is the greatest in the world, but people only have to master 1000 to 2000 words to communicate.

In addition, non-English speakers are allowed to localize English, and create English suitable for themselves, such as Singapore English, Chinese English, Japanese English, Western English, Creole, French English and even Germany English etc. It may also include pidgin English appeared in Shanghai. In short, the dominance of English is represented in that it can tolerate non-English speakers to use broken English, thus making them feel English convenient and close to them, making English more universal.

Thirdly, the universalness of English has a close relationship with its cultural value system. It is universally acknowledged that the cultural value system of Britain and America can encourage more innovation compared with other cultures.

On the other hand, the marketization and technological power of British and American media makes English a dominant language in international communication. The "Hollywood effect" and "silicon valley phenomenon" also worth mentioning here. The former is cultural products, which includes English media, film etc; the later refers to the computer-based and internet-based technical products, all of which swept over the world, thus making English a popular language.

In the end, another reason of the formation of English dominance is that the universal culture appears in English. As mentioned above, $80 \%$ of the documents in the world are written in English. So the universalness of English is because of the universalness it has.

\section{The CHARACTERISTICS OF ENGLiSh DOMINANCE}

Concluded from the above discussion, we can easily find the three characteristics of English dominance.

Firstly, the essence of English dominance is the dominance of English speaking countries. There is no exception in English speaking countries. Currently, the reason for American English taking place of British English is the status of America as the sole superpower in the world. Therefore, although the language spreading around the world is known as English, the content it carries is American culture.

Secondly, this kind of English dominance is irresistible, and it is hard to be changed in a short time. Non-English speaking countries can choose to accept or reject it. But they can't stop the emergence of such an English dominance.

Because of the close connection among language, politics, economy, culture, international communication and other fields, English dominance will inevitably strengthen the dominance of this country in politics, economy, culture and international communication. That is to say, English dominance is not simply the problem of the globalization of English, it will strong impacts on other aspects of other countries.

\section{The Influence OF ENGLISH DOMINANCE}

The influence of English dominance is just like a double edged sword. They can be positive and negative, or both simultaneously. That is, a seemingly negative impact is often accompanied by a favorable side and vice versa. It is very interesting that it is not only applicable to non-English speaking countries, but also applicable to English speaking countries.

\section{A. The Influence of English Dominance on English-speaking Countries}

For English-speaking countries or countries which are using English as their mother tongue, the influence of English should be positive. Firstly, the dominance of English makes these countries more dominant in politics, economy and culture, adversely, the dominance in these fields will strengthen the dominance in English. Secondly, the dominance of English can produce ethnocentrism so that they can feel a sense of honor as an English population. In the long term, this is the biggest benefit English dominance brings to English-speaking countries, because it would make the whole country maintain a strong cohesion. Of course, this sense of superiority and pride differs from country to country, and it 
may be most intense in the superpower America.

However, the strong sense of superiority and pride brought by the dominance also has a negative impact. For example, because of versatility and convenience of English worldwide, people in most English-speaking countries don't have interest to learn about other countries and cultures, and they care less about international news, and don't have intention to learn other languages. It is known that the language skills of people whose mother tongue is English is the worst. In 2000, only 9 students successfully graduated among all the students majored in Arabian in America. While, languages using in UK is the least in Europe. This allows them to be more and more inert, and their thinking way to be more and more rigid.

In addition, the dominance and popularity of English will lead to English variants, such as Singapore English, Chinese English. These variants will not only cause a language barrier but also have a impact on English itself in the USA and UK. It is pointed out in Financial Times that the real challenge confronted by English is from the population which are using English as their second language, because this population has exceeded the English population and it is still increasing. It is predicted in the newspaper that this situation is bound to have a profound influence on English itself.

\section{B. The Influence of English Dominance on Non-English Speaking Countries}

The influence of English dominance on non-English speaking countries may be contrary to the influence on English speaking countries. Its negative impact maybe more than positive impact. The benefits brought by English is that people from different countries can communicate with each other freely. However, language is not just a communication tool, it is also the carrier of culture and signs of identity.

Faced with the irresistance of English dominance, many non-English speaking countries may feel helpless, and may also feel worried about the culture invasion brought by English dominance. Although the impact brought by English dominance is invisible and intangible, they indeed exist and can't be changed in a short time. Some people even think that cultural imperialism is the continuation of colonial policy, but the means is relatively civilized.

Especially for those minority languages, the dominance of English can be devastating, and it may even means extinction of their language, culture and identity. The extinction of language has been existing from the ancient time, but the scale is bigger, and speed quicker. It is said that half of the languages will disappear in middle 21th century, and someone says it is $90 \%$.

For those non-English speaking western countries which also want to be language powerhouse, this helpless psychology becomes more apparent. Currently, although France spends 100 million US dollars to promote French culture every year, French ranks the 9th in the languages around the world. French scientists are clearly aware of the situation. They say that either they publish their articles in English, or die with French quietly.

Thus, the non-English speaking countries will be faced with a dilemma, to integrate into the world to be modernized or to isolate themselves to maintain national character. In order to be modernized, it is necessary to integrate into the world, but this will certainly bring some changes to traditional culture. In the current situation, whether to walk out of this predicament successfully largely determines the ability to effectively deal with the problems caused by English dominance in international communication.

\section{The Influence of English Dominance on China}

English dominance has both positive and negative effects on China. From a positive perspective, the strong direct effect English dominance has brought to China is to promote a popularity of English in our country, thus effectively improving the comprehensive quality and international level of our civil people and improve the environment to communicate with other countries in the world. Just think, if there is no language bridge of English in the past 20 years, what will be the outcome of China's reform and opening up policy? If our country does not introduce English, does not pay special attention to English and does not link English proficiency to education, promotion and other aspects, there can not be an English rush in the past 20 years, which ranges from New Concept English to Crazy English, and there can not be a so-called English economy, a going-abroad rush and an increasing tendency of English media.

In short, without effective absorption of English dominance in the past 20 years, there is no initially internationalized environment for China. Without this environment, the entry into WTO and the success of applying for hosting Olympic Games is unthinkable.

Our experience has shown that, as long as English dominance is handled properly, and English is regarded as a tool to integrate into the world, then it will cost less to develop and modernize our country, narrow lagging time, thus laying a foundation for catch-up.

Of course, many Chinese scholars are worried about the potential dangers English dominance will pose on China. They think that in contemporary info-technical society, language dominance is bound to bring culture dominance, thus emerging new unfairness. This concern is obviously justified. Chinese officials can say WTO. APEC and other English abbreviations very casually just like saying their hometown language. Furthermore, young people are all familiar with English buzzwords.

The famous social linguist Chen Yuan thinks that this is a great wonder of Chinese. It is marvelous that English words can appear so naturally in Chinese without any official requirement. Even though the old don't know what CT means, they can speak out very naturally. 
Then, how do we regard English dominance which brings positive sides as well as potential dangers? How do we regard the side effects English dominance brings to Chinese and Chinese culture? First of all, we do not have to worry groundlessly, viable language are not afraid of foreign language invasion. Any language can not be self-sufficient and some foreign language can enrich their development. From another perspective, the absorption of English words can show the vigor and vitality of Chinese. As a result, faced with English dominance, we should be confident instead of being worried.

Of course, it is also true for culture. The long standing of five-thousand-year long culture relay on the feature of discarding the dross and selecting the essential. The western culture will inevitably have impacts on Chinese culture through English dominance. However, in the long term, if we can absorb the essence of foreign culture, and discard the dross, Chinese culture can get new development and demonstrate its strong vitality.

\section{CONCLUSION}

Before the dominance of English takes shape, other languages have also been dominant for some time in the history. But with the impact of the language-speaking countries,, the dominance of these languages also disappeared. So will the dominance of English disappear in the future just like these languages? The answer is positive, as other languages have undergone ups and downs, English is no exception. Then what is the symbol of the declining tendency of English? The author of the future of English David Graddol thought scientific technology was one of the symbols. We can deny symbol of scientific technology, but I think the declining tendency of English can also be shown in other aspects, after all other, the dominance of one language is supported by other dominances. In fact, the lacking of interest in international journalism of English speaking countries and the ineffciency of learning other languages indicate the inflexibility of these English-speaking countries. In the long run, this maybe the beginning of the declining tendency of English, but we have to acknowledge that this process is long.

\section{REFERENCES}

[1] A World Empire by Other Means: The Triumph of English. (2001). Christmas Special of the Economist. December 22.

[2] China Boosts English. (2001). 21st Century. March 29. 14.

[3] English is the International Language. Financial Times. December 28. 2000.

[4] Stevenson. R. L. (1994). Global Communication in the 21st Century. Longman Publishing Group. New York: Longman.

[5] The Dominance of English: Colleges Worldwide Abandon Their Native Languages for a Common Tongue. (2000). The Chronicle of Higher Education. September 8.

[6] Ulrich Ammon. (2001). The Dominance of English as a Language of Science. Mouton de Gruyter=.

[7] Zhao. Y. \& Keith. P. C. (1998). English in China. World Englishes, 14, 36-37.

Jiao Xue was born in Yangzhou, China in 1986. She received her M.A degree in foreign linguistics and applied linguistics from Jiangsu University of Science and Technology, China in 2011.

She is currently a tutor in Foreign Language Department, Zhenjiang Watercraft College, Zhenjiang, China. Her research interests include second language acquisition and intercultural communication.

Wenjing Zuo was born in Yangzhong, China in 1979. She received her M.A degree in linguistics from Nanjing University, China in 2008 .

She is currently a lecturer in Foreign Language Department, Zhenjiang Watercraft College, Zhenjiang, China. Her research interests include applied linguistics and language teaching. 